\title{
Subcutaneous phaeohyphomycosis caused by Hongkongmyces snookiorum in a kidney transplant patient: a case report
}

\author{
Deng Linqiang ${ }^{1}$, Chen Yiguo' ${ }^{1}$ Xu Heping ${ }^{2}$, Chen Dongke ${ }^{3}$, Hu Longhua ${ }^{4}$, Gui Xiaomei ${ }^{1}$ and Zou Xia ${ }^{\text {* }}$
}

\begin{abstract}
Background: Morbidity and mortality in transplant patients is increased by infection caused mainly by rare opportunistic pathogens. The present study reports a case where Hongkongmyces snookiorum caused subcutaneous phaeohyphomycosis in a kidney transplant patient.

Case presentation: A 47-year old Chinese woman with chronic kidney disease 5 underwent kidney transplantation 3 years ago. Her regular medications included Tacrolimus ( $1 \mathrm{mg}$, two times daily), Mycophenolate Mofetil (two times $250 \mathrm{mg}$, twice daily) and Prednisone acetate tablets ( $5 \mathrm{mg}$ daily). Eighteen months ago, her proximal right index finger was red, painful and swollen. After admission, a hard and fluctuating $1 \mathrm{~cm} \times 1 \mathrm{~cm}$ abscess was found on the dorsal side of the right index finger. Gram and fluorescence staining of a direct smear of a syringe extraction from the abscess revealed presence of filamentous fungi. White velvet colonies ( $2-3 \mathrm{~mm}$ ) were found on blood plate and Sabouraud glucose agar (SGA) after 1 week, and grey aerial hyphae were observed. After 15 days, a 26 $\mathrm{mm}$ gray colony was also observed on SGA. The homology between this filamentous fungus and Hongkongmyces snookiorum ILLS00125755 (Genbank Sequence ID: MH161189.1) was 99.66\%. An in vitro antifungal susceptibility test showed that this filamentous fungus was sensitive to azoles such as itraconazole and voriconazole.
\end{abstract}

Conclusions: We report an opportunistic fungus infection caused by Hongkongmyces snookiorum in a transplant patient. Our finding shows that prevention of subcutaneous fungal infection is necessary for kidney transplantation patients.

Keywords: Kidney transplant; subcutaneous infection; Hongkongmyces snookiorum

\section{Background}

Infection is an important cause of morbidity and mortality in transplant patients $[1,2]$. These infections are typically caused by rare opportunistic pathogens [3-5]. Phaeohyphomycosis is caused by a large heterogeneous group of dematiaceous, or darkly pigmented, fungi. These infections are being increasingly observed in transplant patients [6]. We report for the first time a case of subcutaneous phaeohyphomycosis caused by

\footnotetext{
*Correspondence: zx1977yu1978@163.com

${ }^{1}$ Medical Laboratory, Jiangxi Provincial People's Hospital Affiliated to Nanchang University, Nanchang 330006, China

Full list of author information is available at the end of the article
}

Hongkongmyces snookiorum in a kidney transplant patient.

\section{Case presentation}

A 47-year old Chinese woman with chronic kidney disease 5 underwent kidney transplantation 3 years ago. Her regular medications included Tacrolimus $(1 \mathrm{mg}$, two times daily), Mycophenolate Mofetil (two times $250 \mathrm{mg}$, twice daily) and Prednisone acetate tablets (5 mg daily). Eighteen months ago, her proximal right index finger was red, painful and swollen, with some white pus. After admission, a hard and fluctuating $1 \mathrm{~cm} \times 1 \mathrm{~cm}$ abscess was found on the dorsal side of the right index finger

(c) The Author(s). 2020 Open Access This article is licensed under a Creative Commons Attribution 4.0 International License, which permits use, sharing, adaptation, distribution and reproduction in any medium or format, as long as you give appropriate credit to the original author(s) and the source, provide a link to the Creative Commons licence, and indicate if changes were made. The images or other third party material in this article are included in the article's Creative Commons licence, unless indicated otherwise in a credit line to the material. If material is not included in the article's Creative Commons licence and your intended use is not permitted by statutory regulation or exceeds the permitted use, you will need to obtain permission directly from the copyright holder. To view a copy of this licence, visit http://creativecommons.org/licenses/by/4.0/ The Creative Commons Public Domain Dedication waiver (http://creativecommons.org/publicdomain/zero/1.0/) applies to the data made available in this article, unless otherwise stated in a credit line to the data. 


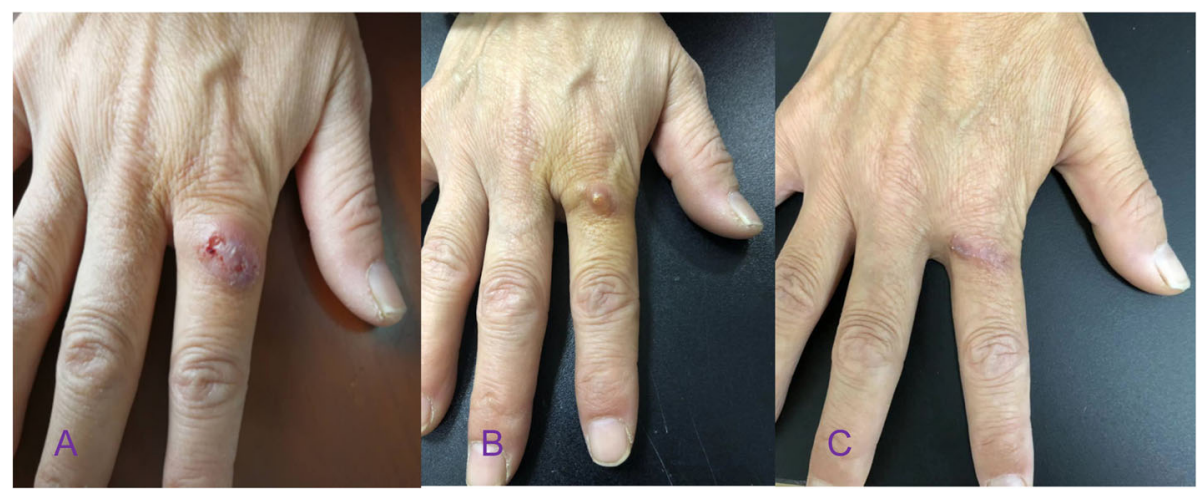

Fig. 1 a Lesion at the time of initial diagnosis, (b) 4 weeks after the first withdrawal, (c) after treatment was continued for a second time

(Fig. 1a). Physical examination showed that the patient was in good general condition. The transplanted kidney was tough, inactive, with no tenderness. No snoring pain, no sputum pain and no negative shifting dullness in the renal area were detected. Digital Radiography (DR) showed soft tissue swelling around the right finger joint and an increased density shadow. Laboratory tests showed that C-Reactive Protein (CRP), blood, urine, stool and coagulation functions were normal, with creatinine $141 \mu \mathrm{mol} / \mathrm{L}$, urea nitrogen $9.4 \mathrm{mmol} / \mathrm{L}$ and slightly increased uric acid, $423 \mu \mathrm{mol} / \mathrm{L}$.

Gram and fluorescence staining of a direct smear from a syringe extraction of the abscess revealed the presence of filamentous fungi (Fig. $2 \mathrm{a}$ and $\mathrm{f}$ ). On the second day, the same filamentous fungus was found on the pathological tissues after crushing when the lesion was stained with Gram stain, Grocott's methenamine silver stain and fluorescent staining (Fig. 2b, d, g).

When the lesion was cultured at $37^{\circ} \mathrm{C}$ or $28^{\circ} \mathrm{C}$ for 3 days, filamentous fungi were observed, but no bacteria. White velvet colonies $(2-3 \mathrm{~mm})$ were found on a blood plate and in Sabouraud glucose agar (SGA) (Fig. 3a, b). After 1 week, grey aerial hyphae were observed (Fig. 3c). After 15 days, a $26 \mathrm{~mm}$ villous gray colony was observed on SGA and many "dew beads"-like exudates were found in the upper layer in the middle of the colony (Fig. 3d). Potato dextrose agar (PDA) (small culture) cultured at $28^{\circ} \mathrm{C}$ for 6 days (Fig. 2e) and 12 days (Fig. 2j) showed separated hyphae but no spores. The mycelium color gradually darkened, which suggested presence of a dark fungus.

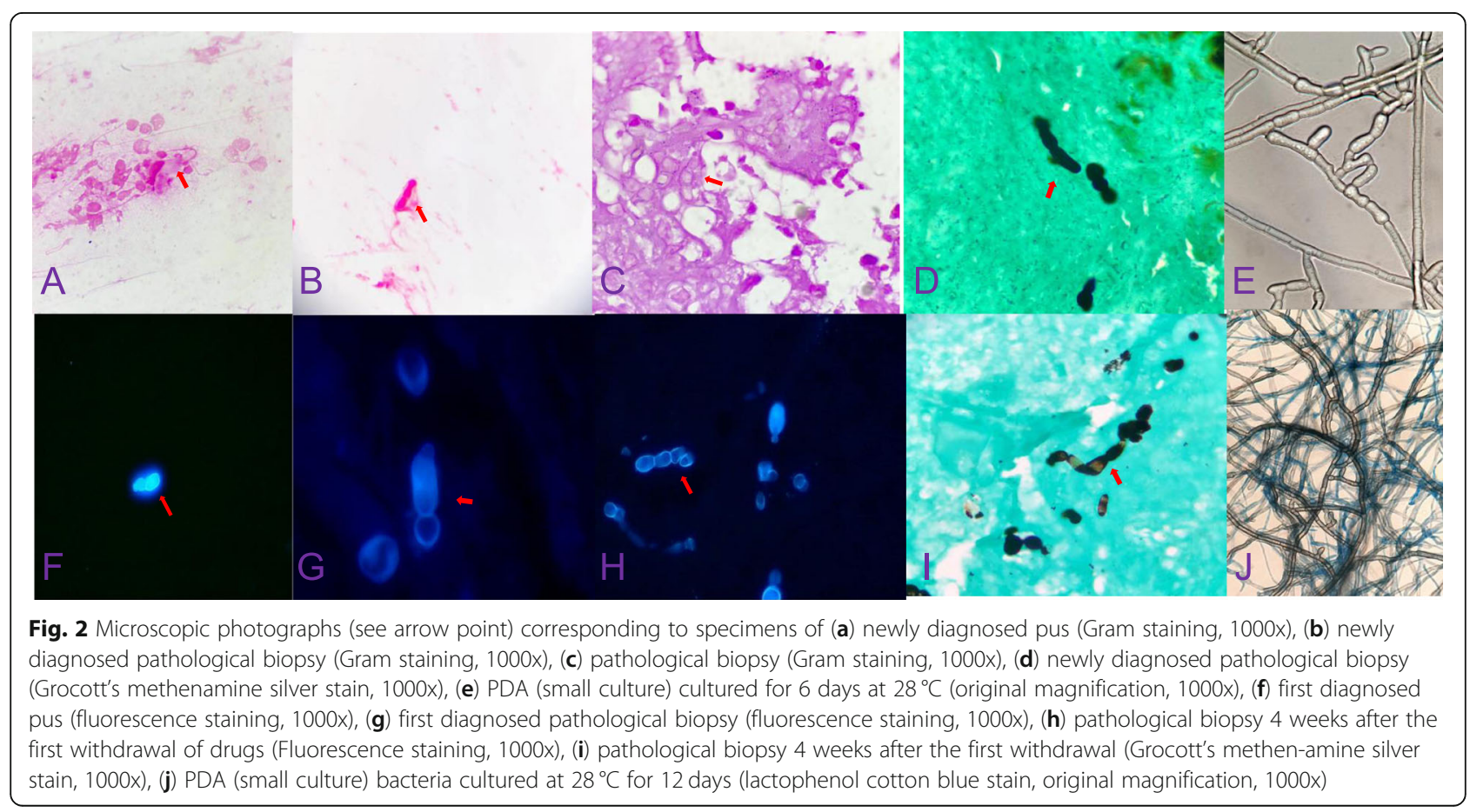



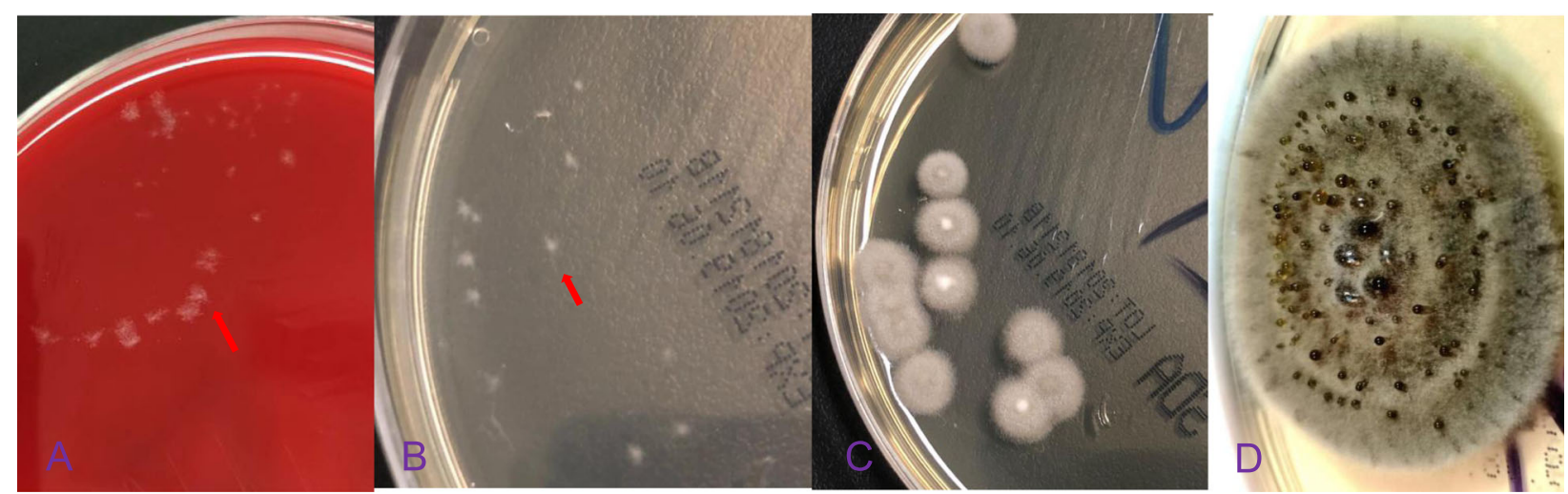

Fig. 3 Fungal cultures. a Colonies cultured for 3 days at $37^{\circ} \mathrm{C}$ in a blood plate, (b) colonies cultured for 3 days at $37^{\circ} \mathrm{C}$ in SGA, (c) colonies cultured at $37^{\circ} \mathrm{C} \mathrm{SGA}$ for 1 week, (d) colonies cultured at $28^{\circ} \mathrm{C}$ PDA for 15 days

In order to identify the final pathogen, we performed DNA (Internal Transcribed Spacer, ITS) gene sequencing and compared the sequence with NCBI and Myobank databases. ITS gene primers were synthesized by Guangzhou Aiji Bio Company (Guangzhou, china) as follows: forward, ITS-1 5' -TCCGTAGGTGAACCTGCG G-3', reverse: ITS-4 5'-TCCTCCGCTTATTGATAT GC-3'. Amplification system $(25 \mu \mathrm{L}): 2 x$ Taq PCR MasterMix $12.5 \mu \mathrm{L}$, double distilled water $8.5 \mu \mathrm{L}, 1 \mu \mathrm{L}$ of primers, $2 \mu \mathrm{L}$ DNA template; amplification procedure: $95^{\circ} \mathrm{C}(5 \mathrm{~min}), 95^{\circ} \mathrm{C}(1 \mathrm{~min}), 55^{\circ} \mathrm{C}(1 \mathrm{~min}), 72{ }^{\circ} \mathrm{C}(1 \mathrm{~min})$, 38 cycles, $72^{\circ} \mathrm{C}$ for $10 \mathrm{~min}$. ITS gene sequences were analyzed by sequence scanner software (version 1.0) (Guangzhou Aiji Bio Company, China) and the quality value $(\mathrm{QV})$ of sequence $>20$ was selected and compared in NCBI and Myo-bank databases. The identification results were analyzed by the guide of CLSI MM18-A. We found that the homology between this filamentous fungus and Hongkongmyces snookiorum ILLS00125755 (Genbank Sequence ID: MH161189.1) was 99.66\%.

The susceptibility of Hongkongmyces snookiorum to three antifungal drugs (amphotericin B, voriconazole and itraconazole) was tested using an E-test method (Trek Diagnostic Systems, East Grinstead, UK), performed according to the manufacturer's protocol for filamentous fungi. Briefly, Hongkongmyces snookiorum was cultured at $28{ }^{\circ} \mathrm{C}$ for 7 days. The concentration of hyphal fragments was adjusted to $1.0 \mathrm{McF}$ arland standard (refer to CLSI M38-2A). A sterile cotton swab was immersed in the adjusted bacterial suspension. Excessive bacterial suspension was extruded on the wall of the tube, and streaked on the fungal drug sensitive agar plate. After 3$5 \mathrm{~min}$ at room temperature, E-test (Zhengzhou Antu Bio, China) was added to the plate and incubated at $35^{\circ} \mathrm{C}$ for 7 days. The minimum inhibitory concentration in the E-test was obtained following manufacturer's instructions. The test was performed in duplicate. The strain used for quality control was Candida albicans
ATCC90028. The antifungal susceptibility test (E-test) showed sensitivity to azoles such as itraconazole and voriconazole, with MIC of 0.012 and $0.008 \mu \mathrm{g} / \mathrm{mL}$, respectively, although resistance was observed against amphotericin B (MIC: $4 \mu \mathrm{g} / \mathrm{ml})$. Administration of oral voriconazole (100 mg twice daily) combined with an operation resection was effective in the treatment of the lesion.

\section{Discussion and conclusions}

Phaeohyphomycosis is caused by a large, heterogenous group of dematiaceous, or darkly pigmented fungi. Hongkongmyces snookiorum belongs to the fungal family Lindgomycetaceae, in the order Pleosporales within the class Dothideomycetes. Hongkongmyces snookiorum has been found only in Pennsylvania, USA, isolated from submerged detritus from a fresh water fen. Among its sister taxa, only Hongkongmyces pedis was associated to human infections previously [7-13].

Our results show that the isolated fugus can produce mycelium but no spores when cultured on SGA and PDA for 30 days at $28^{\circ} \mathrm{C}$ and $37^{\circ} \mathrm{C}$, respectively. The fungus was not identified by Matrix Assisted Laser Desorption Ionization - Time of Flight (MALDI-TOF) (bioMérieux, France and Jiangsu Skyray Instrument, China) probably because its limited presence in databases [14, 15]. When identified by DNA sequencing, its ITS1 sequence was longer and more variable than in related members of the Lindgomycetaceae family (about $500 \mathrm{bp}$ ) [16]. We further sequenced the ITS gene of the fungus using universal primers ITS- 1 and ITS-4, and found that the homology between this isolated fungus and Hongkongmyces snookiorum ILLS00125755 (Genbank Sequence ID: MH161189.1) is $99.66 \%$.

The patient is a 47-year-old woman with a kidney transplant that was exposed to long-term use of antirejection and immunosuppressive agents and hormones, such as tacrolimus, mycophenolate mofetil and 
prednisone acetate. These risk factors may be causing opportunistic fungal infections. As a farmer and a housewife, the patient has lived in a hilly region of southern China for a long time and may be exposed to such fungi.

Invasive skin and subcutaneous infections caused by demalaceous fungi are transmitted through wounds, which are often neglected by patients. The patient could not describe exactly the cause of the wound or when it appeared. The same hypha was found in smear and cultures of pus specimens and biopsies from the patient. Combination of local septic granule inflammatory, those evidences above suggested the patient did have a Hongkongmyces snookiorum infection.

After the patient was discharged from the hospital, the infection symptoms were controlled by administration of oral voriconazole, $100 \mathrm{mg}$ twice a day for 4 weeks. However, when the patient stopped taking the drug, the lesion pain and ulceration reappeared after 2 weeks at the same site, with several small nodules around it. The size was approximately $0.3 \mathrm{~cm} \times 0.2 \mathrm{~cm} \times 0.1 \mathrm{~cm}$ (Fig. $1 \mathrm{~b}$ ), and histopathological features were similar to previous results (Fig. 2c, h, i). The patient was again given voriconazole orally, $100 \mathrm{mg}$ twice daily, and the condition improved significantly after 4 weeks (Fig. 1c). No recurrence was found after a ten-month follow-up.

Thus, kidney transplantation patients must pay attention to prevent subcutaneous fungal infection.

\section{Abbreviations \\ SGA: Sabouraud glucose agar; PDA: Potato dextrose agar;; DR: Digital Radiography; CRP: C-Reactive Protein; DNA: Deoxyribonucleic acid; ITS: Internal Transcribed Spacer gene; MIC: Minimal inhibitory concentration; MALDI-TOF: Matrix Assisted Laser Desorption Ionization - Time of Flight}

\section{Acknowledgments}

The authors would like to express their gratitude to EditSprings (https:// www.editsprings.com/) for the expert linguistic services provided.

\section{Authors' contributions}

Authors DLQ, XHP, CDK, HLH, GXM and ZX contributed to patient care, collection of information and writing of the manuscript. Author CYG contributed to writing, final editing, and approval of the manuscript. All authors have approved the final version before publication.

\section{Funding}

None declared.

\section{Availability of data and materials}

All data generated or analyzed during this study are included in this published article.

\section{Ethics approval and consent to participate}

Informed consent from the patient was provided, The study was approved by the research ethics.

committee of the Jiangxi Provincial People's Hospital Affiliated to Nanchang University (Registration.

No. 2018057). The authors have no financial conflicts of interest.

\section{Consent for publication}

Informed written consent for publication was obtained from the patient prior to collecting information.

The patient gave written consent for their personal or clinical details along with any identifying images. to be published in this study.

\section{Competing interests}

The authors declare that they have no competing interests.

\section{Author details}

${ }^{1}$ Medical Laboratory, Jiangxi Provincial People's Hospital Affiliated to Nanchang University, Nanchang 330006, China. ${ }^{2}$ Medical Laboratory, the First Affiliated Hospital of Xiamen University, Xianen 361003, China. ${ }^{3}$ Department of Laboratory Medicine, Beijing Hospital, National Center of Gerontology, Beijing 100730, China. ${ }^{4}$ Medical Laboratory, the Second Affiliated Hospital of Nanchang University, Nanchang 330006, China.

Received: 26 March 2020 Accepted: 26 July 2020

Published online: 01 August 2020

\section{References}

1. Torres-Sanchez MJ, Hernandez-Garcia E, Gomez-Sanchez J, Palomares-Bayo M, Pena-Ortega M, Galindo-Sacristan P, et al. Severe Scedosporium apiospermum infection in a recent renal transplant recipient: case report. Transplant Proc. 2018;50(2):683-4. https://doi.org/10.1016/j.transproceed. 2017.09.051

2. Yu MY, Yong CK, Lee JP, Lee H, YSJC K. Nephrology E: death with graft function after kidney transplantation: a single-center experience. Clin Exp Nephrol. 2018:22(3):710-8.

3. Centellas Perez FJ, Martinez Antolinos C, Piqueras Sanchez S, Lorenzo Gonzalez I, Llamas Fuentes F, Gomez Roldan C. Scedosporium apiospermum infection in a kidney transplant recipient. Rev Iberoam Micol. 2019:36(1):48-50. https://doi.org/10.1016/j.riam.2018.10.005.

4. Kristensen AA, Horneland R, Birn H, MJBCR S. Giardia lamblia infection after pancreas-kidney transplantation. Case Rep. 2016;2016:bcr2015211515.

5. Su HL, Huh KH, Dong JJ, Kim MS, Kim SI, Lee J, et al. Risk factors for Pneumocystis jirovecii pneumonia (PJP) in kidney transplantation recipients. Sci Rep. 2017;7(1):1571.

6. Revankar SG. Phaeohyphomycosis in transplant patients. J Fungi (Basel). 2015;2(1):E2. https://doi.org/10.3390/jof2010002 Review.

7. Abdel-Aziz FA, MAJM-IN A-W. Lolia aquatica gen. Et sp. nov. (Lindgomycetaceae, Pleosporales), a new coelomycete from freshwater habitats in Egypt. Mycotaxon. 2010;114(7):33-42.

8. Crous PW, Wingfield MJ, Burgess TI, Hardy G, Gene J, Guarro J, et al. Fungal planet description sheets: 716-784. Persoonia. 2018;40:240-393. https://doi. org/10.3767/persoonia.2018.40.10.

9. Hirayama K, Tanaka K, Raja HA, Miller AN, Shearer CA. A molecular phylogenetic assessment of Massarina ingoldiana sensu lato. Mycologia. 2010;102(3):729-46.

10. Hyde KDJASB. Tropical Australian freshwater fungi. VI*. Tiarosporella paludosa and Clohesyomyces aquaticus gen. Et sp. nov. (Coelomycetes). Aust Syst Bot. 1993;6(2):169-73.

11. Raja HA, Tanaka K, Hirayama K, Miller AN, Shearer CA. Freshwater ascomycetes: two new species of Lindgomyces (Lindgomycetaceae Pleosporales, Dothideomycetes) from Japan and USA. Mycologia. 2011; 103(6):1421-32. https://doi.org/10.3852/11-077.

12. Raja HA, Oberlies NH, El-Elimat T, Miller AN, Zelski SE, Shearer CAJM Lindgomyces angustiascus, (Lindgomycetaceae, Pleosporales, Dothideomycetes), a new lignicolous species from freshwater habitats in the USA. Mycoscience. 2013;54(5):353-61.

13. Tsang CC, Chan JF, Trendell-Smith NJ, Ngan AH, Ling IW, Lau SK, et al. Subcutaneous phaeohyphomycosis in a patient with lgG4-related sclerosing disease caused by a novel ascomycete, Hongkongmyces pedis gen. Et sp. nov: first report of human infection associated with the family Lindgomycetaceae. Med Mycol. 2014;52(7):736-47. https://doi.org/10.1093/ $\mathrm{mmy} / \mathrm{my} \mathbf{0} 043$

14. Lau AF, Drake SK, Calhoun LB, Henderson CM, Zelazny AM. Development of a clinically comprehensive database and a simple procedure for identification of molds from solid media by matrix-assisted laser desorption ionization-time of flight mass spectrometry. J Clin Microbiol. 2013;51(3):828.

15. Ranque $\mathrm{S}$, Normand AC, Cassagne C, Murat JB, Bourgeois N, Dalle F, et al. MALDI-TOF mass spectrometry identification of filamentous fungi in the clinical laboratory. Mycoses. 2014;57(3):135-40. https://doi.org/10.1111/myc. 12115. 
16. Korabecna M. The variability in the fungal ribosomal DNA (ITS1, ITS2, and 5. $8 \mathrm{~S}$ rRNA Gene): ITS biological meaning and application in medical mycology. Commun Curr Res Educ Topics Trends Appl Microbiol. 2007;2: 783.

\section{Publisher's Note}

Springer Nature remains neutral with regard to jurisdictional claims in published maps and institutional affiliations.

Ready to submit your research? Choose BMC and benefit from:

- fast, convenient online submission

- thorough peer review by experienced researchers in your field

- rapid publication on acceptance

- support for research data, including large and complex data types

- gold Open Access which fosters wider collaboration and increased citations

- maximum visibility for your research: over $100 \mathrm{M}$ website views per year

At BMC, research is always in progress.

Learn more biomedcentral.com/submissions 